\title{
The wing phalanges (phalanx proximalis digiti majoris) of Gaviiformes, Podicipediformes, Pelecaniformes, Ardeiformes, Anseriformes, Gruiformes, Ralliformes, Charadriiformes and Galliformes
}

\author{
Jenő (Eugen) KessLeR ${ }^{1 *} \&$ Ida HorvÁth ${ }^{2}$
}

Received: December 21, 2020 -Received: May 26, 2021 -Accepted: May 27, 2021

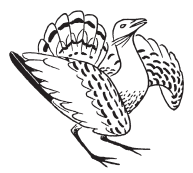

Kessler, J. (E.) \& Horváth, I. 2020.The wing phalanges (phalanx proximalis digiti majoris) of Gaviiformes, Podicipediformes, Pelecaniformes, Ardeiformes, Anseriformes, Gruiformes, Ralliformes, Charadriiformes, and Galliformes. - Ornis Hungarica 29(1): 149-169. DOI: 10.2478/orhu-2021-0012

\begin{abstract}
The authors compared the first phalanx of the second wing-finger of 93 species belong to 9 order (Gaviiformes -2 species, Podicipediformes -4 species, Pelecaniformes -4 species, Ardeiformes -12 species, Anseriformes -27 species, Gruiformes -4 species, Ralliformes -6 species, Charadriiformes -25 species and Galliformes -9 species). The importance of studying this bone lies in the fact that, although it has diagnosable characteristics, it was practically neglected by osteologists and paleontologists. Thus, fossil materials can be identified through them, as well as those from owl pellets. The comparison was made possible by the comparative avian skeleton collection of the Hungarian Natural History Museum. The text is supplemented by 10 figures and 1 table.
\end{abstract}

Keywords: Europe, waterfowl, Galliformes, phalanx proximalis digiti majoris, osteology

Összefoglalás A szerzők 9 rendbe tartozó, összesen 93 madárfaj szárnyának második ujj első ujjpercét vetették összehasonlító vizsgálat alá (Gaviiformes - 2 faj, Podicipediformes - 4 faj, Pelecaniformes -4 faj, Ardeiformes - 12 faj, Anseriformes - 27 faj, Gruiformes - 4 faj, Ralliformes - 6 faj, Charadriiformes - 25 faj, Galliformes - 9 faj). A vázrész tanulmányozásának jelentősége abban áll, hogy bár jól meghatározható jellegekkel rendelkezik, gyakorlatilag elhanyagolták a csonttannal és őslénytannal foglalkozók. Általuk mind recens, mind fosszilis anyagok jól meghatározhatóak. A vizsgálatot a Magyar Természettudományi Múzeum összehasonlító madárcsont gyüjtemény anyaga tette lehetővé. A szöveget 10 ábra és 1 táblázat egészíti ki.

Kulcsszavak: Európa, vízimadarak, tyúkalakúak, phalanx proximalis digiti majoris, csonttan

\footnotetext{
${ }^{1}$ Department of Paleontology, Eötvös Loránd University, 1117 Budapest, Pázmány Péter sétány 1/c, Hungary

${ }^{2}$ Institute of Biology, Eötvös Loránd University, 1117 Budapest, Pázmány Péter sétány 1/c, Hungary,

*corresponding author, e-mail: kessler_jeno@yahoo.com
} 


\section{Introduction}

The current study discusses a less known part of the avian skeleton used for description. The bone is rather small (even in the case of the largest avian species it is only 6-7 centimeters long) and relatively simple in appearance. The first phalanx of the second wing-finger bears excellent diagnostic characteristics.

Out of the four wing phalanges, only this has such morphological characteristics that can be used for comparative anatomical, paleontological, archeological, taxonomical or ornithological examinations of owl pellets.

In this investigation the bird order Ardeiformes has traditionally been handled as distinct order from other bird groups due to their bone characters (Brodkorb 1963, Feduccia 1967). Recently, this classification has been used in the non-taxonomic sense because more recent studies suggested that herons are belonging to the order Pelecaniformes (Hackett et al. 2008, Smith 2010).

The morphological terminology and measurement method of the skeletal part was used based on the works of Baumel et al. 1979 and Kessler 2013 (Figure 1/1-2). Depictions and discussions regarding the wing phalanx can only rarely be found within the literature, e.g. in the works of Milne-Edwards 1867-1868, Solti 1980, 1981a, 1981b, 1996, Gilbert et al. 1981, Cohen \& Serjeantson 1996, Kessler 2015, 2016a, 2016b, 2019, 2020.

The sizes given in Table 1 are for information purposes only. The measurement data are derived, on the one hand, from the weighing of specimens from the Natural History Museum of Hungary Budapest comparative bone collection and, on the other hand, from the dimensions of the wing span in the ornithological literature of the species concerned.

\section{Abbreviations}

MTM/NHMUS: Natural History Museum of Hungary Budapest, Department of Paleontology and Geology

A - total length

$\mathrm{C}$ - the width of the proximal end

$\mathrm{E}$ - the largest width of the middle phalanx

$\mathrm{F}$ - the width of the distal end

New genus, sp. name - Gill et al. 2020

We used the following anatomical terminology (Figure 1):

Facies articularis metacarpalis - this is the proximal end

Margo dorsalis - this is the largest width of the middle phalanx

Facies articularis phalangealis - this is the distal end

Osteological description

In the case of loons, grebes, pelicans and cormorants (Figure 2/1-10):

a). Facies articularis metacarpalis:

- strongly protuberant: Podiceps auritus, P. grisegena; 


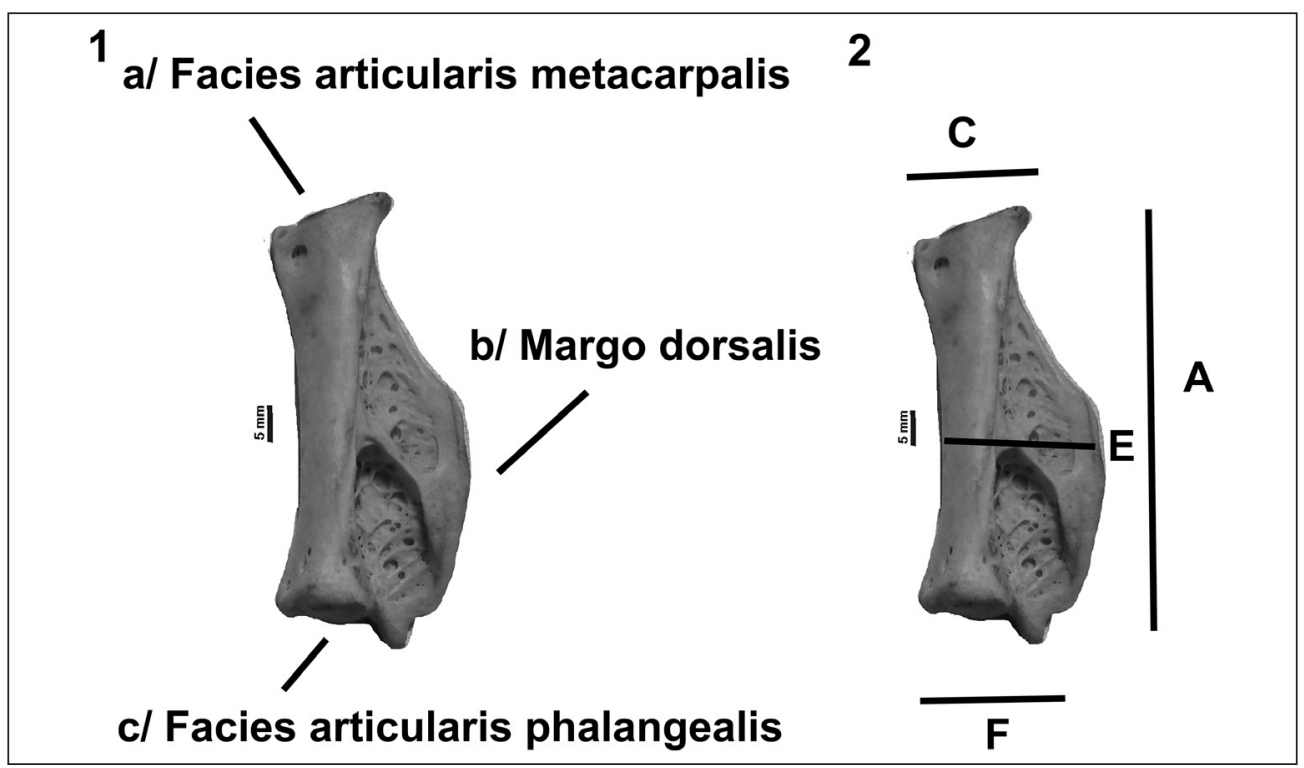

Figure 1. Pelecanus onocrotalus (Linnaeus, 1758)

1. Phalanx proximalis digiti majoris osteology characteristics:

a. proximal end - facies articularis metacarpalis; b. the dorsal side - margo dorsalis; c. distal end - facies articularis phalangealis;

2. Measurements methods of bone:

A. total length; C. breadth of the proximal end; E. breadth of the corpus; F. breadth of the distal end;

1. ábra Pelecanus onocrotalus (Linnaeus, 1758)

1. A nagy (középső) kézujj első ujjperce csonttani jellegei: a. proximális vég - facies articularis metacarpalis; b. dorzális oldal - margo dorsalis; c. disztális vég - facies articularis phalangealis;

2. A csont mérési mintái:

A. teljes hossz; C. proximális vég szélessége; E. a test szélessége; F. a disztális vég szélessége

- strongly protuberant, with a pointed cone shaped dorsal projection: Gavia stellata;

- slightly protuberant: Gavia arctica;

- with two bulges: Phalacrocorax carbo;

- obliquely cut, lifting from the ventral end towards the dorsal, ending in a pointed cone: Pelecanus crispus, P. onocrotalus, Podiceps nigricollis;

- obliquely cut, lifting from the ventral end towards the dorsal, ending in a blunt cone: Phalacrocorax pygmaeus;

- concave with a dorsal and a ventral pointed projection: Podiceps cristatus;

b). Margo dorsalis:

- forms a regular arc: Gavia stellata, Phalacrocorax carbo;

- the arc is strongly protuberant and is asymmetrical: Pelecanus crispus, P. onocrotalus;

- has a regular arc, is slightly protuberant: Podiceps cristatus, P. grisegena, P. nigricollis;

- the middle of the arc is cut straight: Gavia arctica, Podiceps auritus;

- the slightly protuberant arc is wavy: Phalacrocorax pygmeus; 


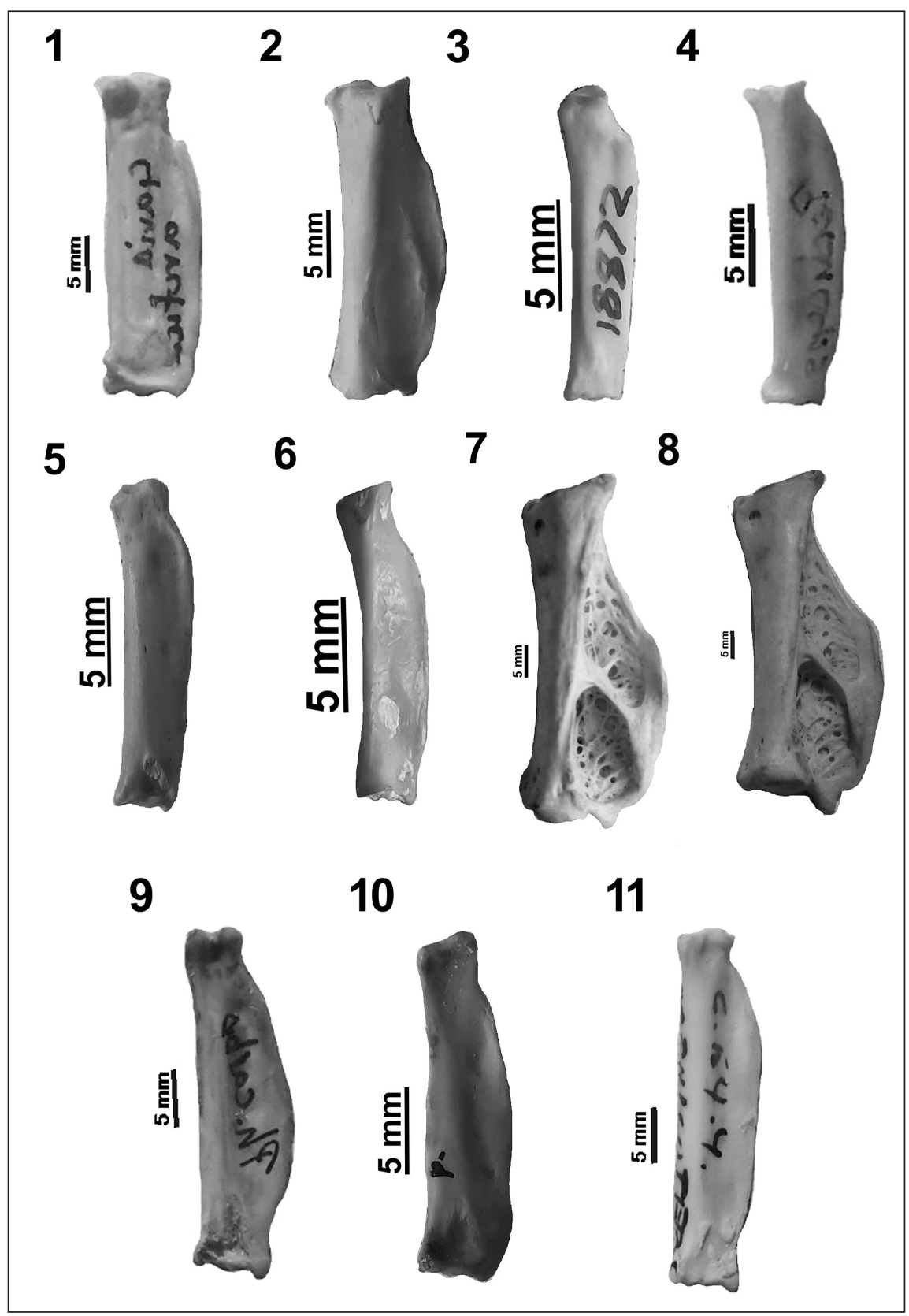

Figure 2. Left phalanx proximalis digiti majoris (ventral aspect)

2. ábra Bal oldali kézujjperc (1. ujjperc, Il. ujj, hasi nézet)

1. Gavia arctica (Linnaeus, 1758); 2. Gavia stellata (Pontoppidan, 1753); 3. Podiceps auritus (Linnaeus, 1758); 4. Podiceps cristatus (Linnaeus, 1758); 5. Podiceps grisegena (Boddaert, 1783); 6. Podiceps nigricollis (Brehm, 1831); 7. Pelecanus crispus (Bruch, 1832); 8. Pelecanus onocrotalus (Linnaeus, 1758); 9. Phalacrocorax carbo (Shaw et Nodder, 1801); 10. Phalacrocorax pygmaeus (Pallas, 1773); 11. Phoenicopterus ruber (Pallas, 1811) 
c). Facies articularis phalangealis:

- oblique, with a strongly protruding dorsal projection: Pelecanus onocrotalus;

- straight, strongly protuberant, with a small dorsal projection: Gavia stellata, Pelecanus crispus;

- wavy, with a strongly protruding dorsal and ventral projection: Phalacrocorax carbo;

- wavy, with a slightly protruding dorsal projection: Gavia arctica; Phalacrocorax pygmeus, Podiceps auritus, P. cristatus, P. grisegena, P. nigricollis;

In the case of herons, ibises, flamingos (Figure 2/11, Figure 3/1-11):

a). Facies articularis metacarpalis:

- strongly protuberant: Bubulcus spp., Ciconia nigra;

- strongly protuberant, pointed, with a small dorsal projection pointing upward: Ardeola spp.;

- slightly protuberant, with a rounded ventral end: Phoenicopterus spp., Plegadis spp.;

- a straight, protuberant ventral and a small pointed projection pointing upward: Botaurus spp.;

- obliquely cut, lifting from the ventral end towards the dorsal: Ciconia ciconia, Platalea spp.;

- straight and wavy: Ardea purpurea;

- oblique and wavy: Ardea cinerea, Egretta spp.;

- oblique and wavy, with a strongly protruding pointed dorsal and ventral projection: Nycticorax;

b). Margo dorsalis:

- forms a regular, strongly protuberant arc: Bubulcus spp., Botaurus spp., Plegadis spp.;

- the ark is slightly protuberant: Platalea spp.;

- asymmetrically protuberant: Ciconia nigra;

- the middle of the arc is cut straight: Ardea cinerea, A. purpurea, Ardeola spp., Ciconia ciconia, Egretta spp., Nycticorax spp., Phoenicopterus spp.;

c). Facies articularis phalangealis:

- oblique, with a strongly protruding dorsal projection: Bubulcus spp., Ciconia ciconia, C. nigra;

- straight wavy, with a slightly protruding dorsal projection: Ardea cinerea, A. purpurea, Ardeola spp., Botaurus spp., Egretta spp., Nycticorax spp., Platalea spp.;

- straight wavy, with a strongly protruding dorsal projection: Phoenicopterus spp.,

- concave, with a strongly protruding dorsal projection: Plegadis spp.;

In the case of geese, swans, shelducks (Figure 4/1-9):

a). Shape of facies articularis metacarpalis:

- oblique and wavy: Anser albifrons;

- cut straight with an oblique, strongly protruding dorsal tip: Anser erythropus, A. fabalis, Branta ruficollis;

- cut straight with an oblique, slightly protruding dorsal tip: Anser anser, Cygnus cygnus;

- protuberant, with a strongly protruding dorsal projection: Tadorna spp.;

- slightly protuberant, with a small dorsal projection pointing upward: Branta bernicla;

- slightly concave: Cygnus olor; 


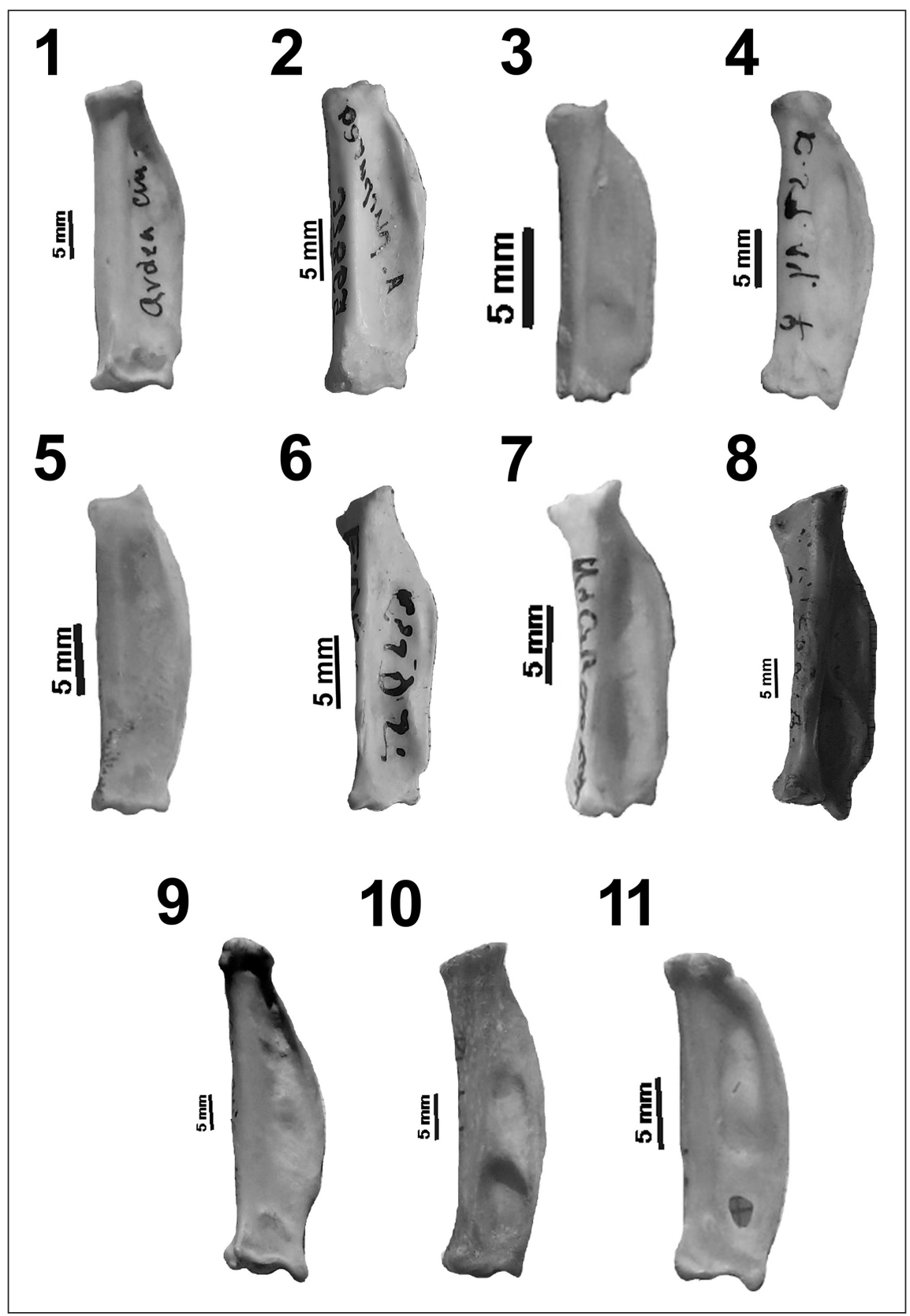

Figure 3. Left phalanx proximalis digiti majoris (ventral aspect)

3. ábra Bal oldali kézujjperc (1. ujjperc, Il. ujj, hasi nézet)

1. Ardea cinerea (Linnaeus, 1758); 2. Ardea purpurea (Linnaeus, 1758); 3. Ardeola ralloides (Scopoli, 1769); 4. Bubulcus ibis (Linnaeus, 1758); 5. Botaurus stellaris (Linnaeus, 1758); 6. Egretta garzetta (Linnaeus, 1766); 7. Nycticorax nycticorax (Linnaeus, 1758); 8. Ciconia ciconia (Linnaeus, 1758); 9. Ciconia nigra (Linnaeus, 1758); 10. Platalea leocorodia (Linnaeus, 1758); 11. Plegadis falcinellus (Linnaeus, 1766) 


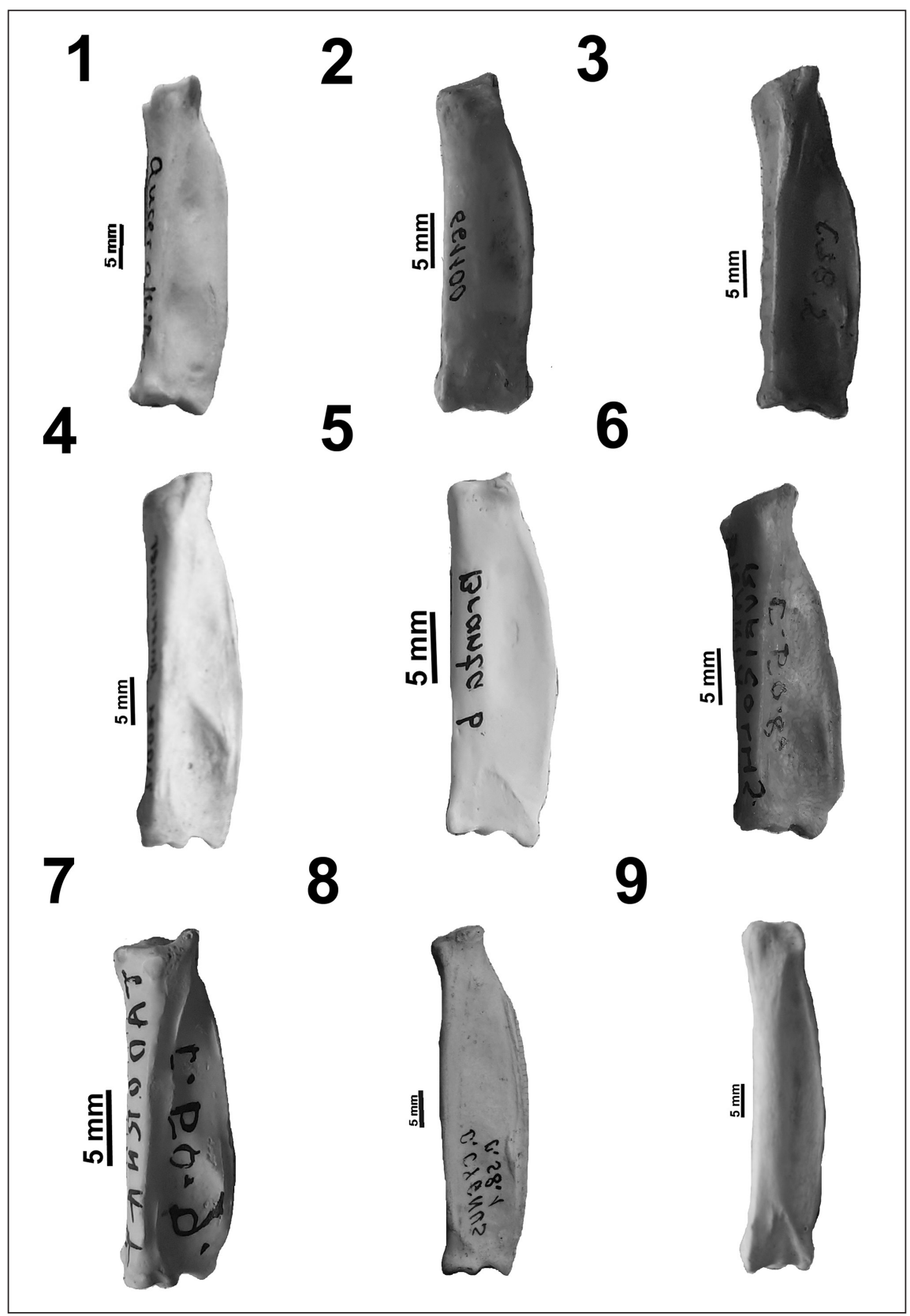

Figure 4. Left phalanx proximalis digiti majoris (ventral aspect)

4. ábra Bal oldali kézujjperc (1. ujjperc, Il. ujj, hasi nézet)

1. Anser albifrons (Scopoli, 1769); 2. Anser anser (Linnaeus, 1758); 3. Anser erythropus (Linnaeus, 1758); 4. Anser fabalis (Latham, 1790); 5. Branta bernicla (Linnaeus, 1758); 6. Branta ruficollis (Pallas, 1769); 7. Tadorna tadorna (Linnaeus, 1758); 8. Cygnus cygnus (Linnaeus, 1758); 9. Cygnus olor (Gmelin, 1789) 
b). The arc of the margo dorsalis:

- strongly protuberant: Anser erythropus, Branta bernicla, B. ruficollis, Tadorna spp.;

- moderately protuberant: Anser albifrons, A. anser, A. fabalis, Cygnus cygnus;

- slightly protuberant: Cygnus olor;

c). The shape of the facies articularis phalangealis:

- symmetrically wavy, with a slightly protruding dorsal projection: Anser albifrons, A. anser, A. erythropus, A. fabalis, Branta ruficollis, Cygnus cygnus, C. olor;

- symmetrically wavy, with a strongly protruding dorsal projection: Branta bernicla;

- asymmetrically wavy: Tadorna spp.;

In the case of diving ducks, tumblers (Figure 5/1-11):

a). Shape of facies articularis metacarpalis:

- slightly obliquely cut: Anas acuta, A. platyrhynchos;

- strongly obliquely cut, with a small pointed ventral and well-developed blunt dorsal projection: Anas clypeata;

- strongly obliquely cut, with a well-developed pointed dorsal projection: Anas strepera;

- slightly protuberant and obliquely cut, with a well-developed pointed dorsal projection: Aythya ferina;

- straight, with a small, pointed conelike projection: Anas querquedula, Aythya nyroca;

- strongly protuberant: Aythya fuligula;

- slightly protuberant: Aythya marila;

- concave: Anas crecca, A. penelope;

b). The arc of the margo dorsalis:

- the bulge is cut: Anas crecca;

- strongly protuberant, slightly wavy: Anas clypeata, A. penelope, A. querquedula, A. strepera;

- moderately and regularly protuberant: Anas acuta, Aythya ferina, A. nyroca;

- slightly protuberant: Anas platyrhynchos, Aythya fuligula, A. marila;

c). The shape of the facies articularis phalangealis:

- cut straight, slightly wavy, with a well-developed dorsal projection: Anas acuta, A. clypeata, A. crecca, A. penelope, A. platyrhynchos, A. querquedula, A. strepera, Aythya ferina, A. fuligula;

- cut straight, slightly wavy, with an underdeveloped dorsal projection: Aythya marila, A. nyroca;

In the case of sea ducks, mergansers (Figure 6/1-7):

a). Shape of facies articularis metacarpalis:

- slightly obliquely cut with a runded dorsal projection: Mergellus albellus;

- strongly obliquely cut, with a runded ventral and well-developed pointed dorsal projection: Bucephala spp.;

- strongly obliquely cut, with a weakly-developed pointed dorsal projection: Melanitta spp.;

- slightly protuberant and obliquely cut, with a well-developed pointed dorsal projection: Clangula spp.; 


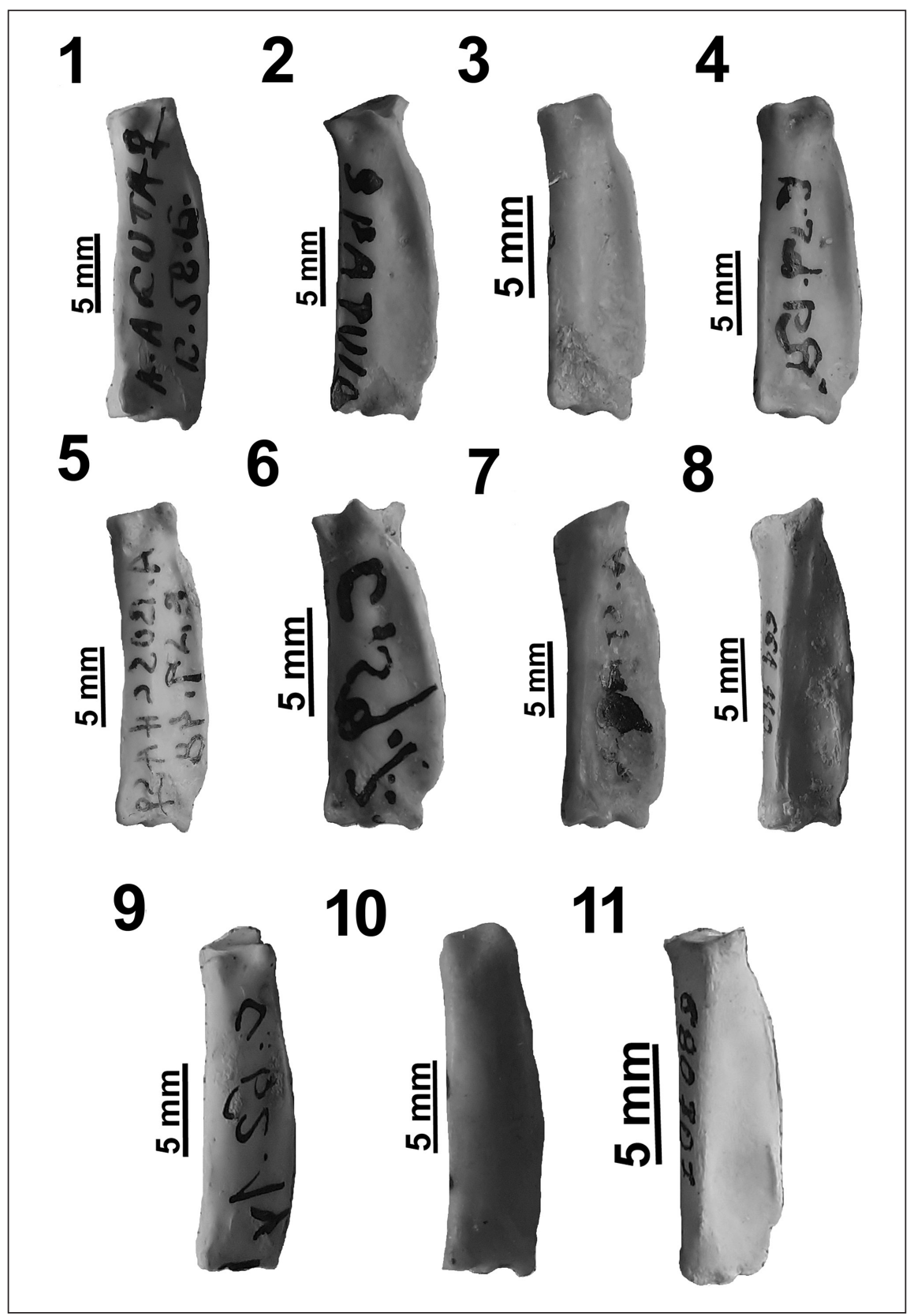

Figure 5. Left phalanx proximalis digiti majoris (ventral aspect)

5. ábra Bal oldali kézujjperc (1. ujjperc, II. ujj, hasi nézet)

1. Anas acuta (Linnaeus, 1758); 2. Anas clypeata (Linnaeus, 1758); 3. Anas crecca (Linnaeus, 1758); 4. Anas penelope (Linnaeus, 1758); 5. Anas plathyrhynchos (Linnaeus, 1758); 6. Anas strepera (Linnaeus, 1758); 7. Anas querquedula (Linnaeus, 1758); 8. Aythya ferina (Linnaeus, 1758); 9. Aythya fuligula (Linnaeus, 1758); 10. Aythya marila (Linnaeus, 1761); 11. Aythya nyroca (Güldenstadt, 1769) 


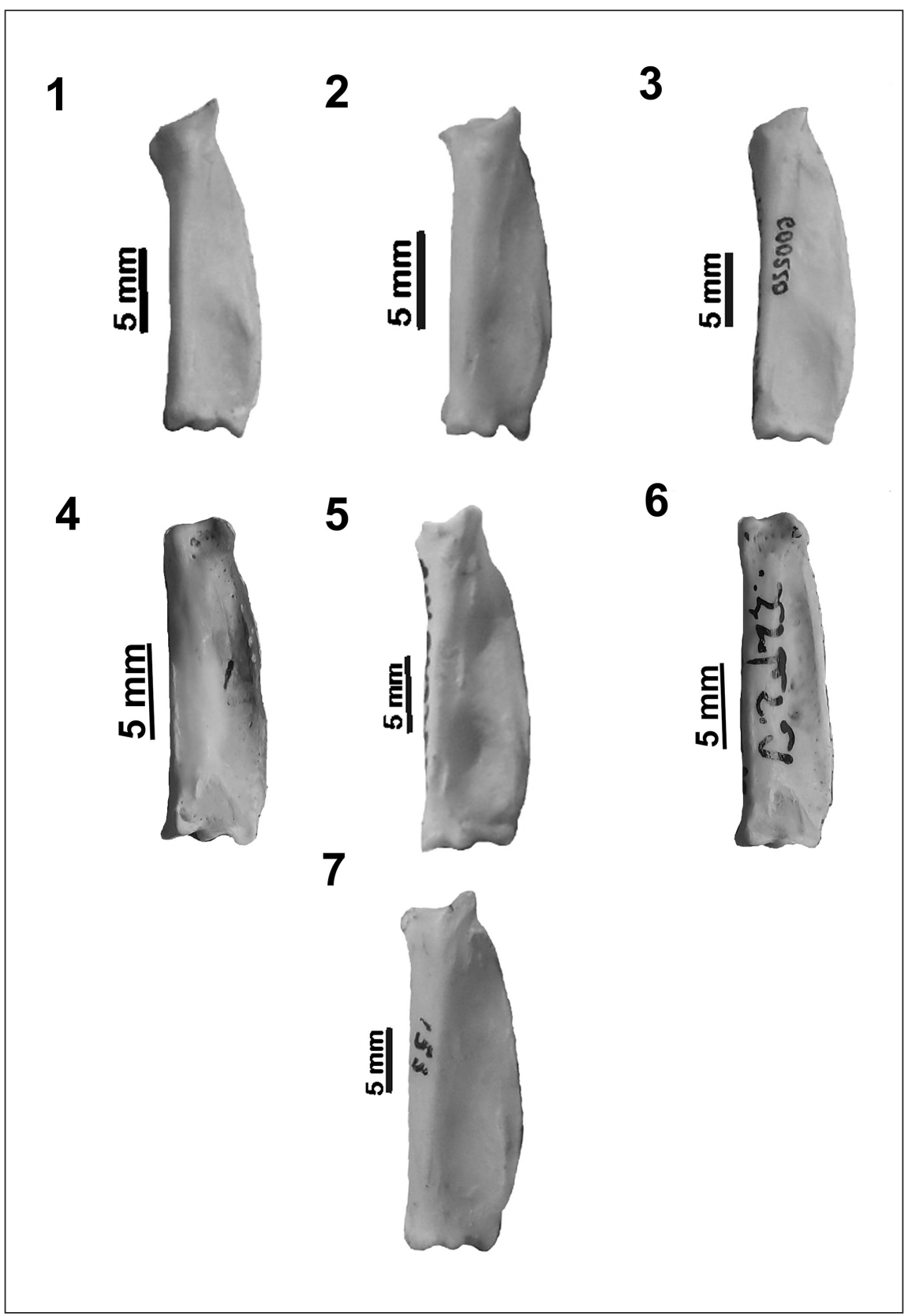

Figure 6. Left phalanx proximalis digiti majoris (ventral aspect)

6. ábra Bal oldali kézujjperc (1. ujjperc, II. ujj, hasi nézet)

1. Bucephala clangula (Linnaeus, 1758); 2. Clangula hyemalis (Linnaeus, 1758); 3. Mellanita nigra (Linnaeus, 1758); 4. Mergus albellus (Linnaeus, 1758); 5. Mergus merganser (Linnaeus, 1758); 6. Mergus serrator (Linnaeus, 1758); 7. Somateria mollissima (Linnaeus, 1758) 
- straight, with a pointed conelike projection: Mergus merganser, Somateria spp.;

- concave: Mergus serrator;

b). The arc of the margo dorsalis:

- the bulge cut obliquely: Mergus serrator;

- strongly and regularly protuberant: Bucephala spp., Clangula spp., Melanitta spp., Mergus merganser, Somateria spp.;

- slightly protuberant: Mergellus albellus;

c). The shape of the facies articularis phalangealis:

- cut straight, wavy, with a well-developed dorsal projection: Bucephala spp., Clangula spp.;

- cut straight, slightly wavy, with an underdeveloped dorsal projection: Melanitta, Mergellus albellus, M. merganser, M. serrator, Somateria spp.;

In the case of cranes, bustards, coots, rails (Figure 7/1-10):

a). Shape of facies articularis metacarpalis:

- obliquely cut, with a well-developed dorsal pointed tip: Otis tarda, O. tetrax;

- obliquely cut, with a slightly developed dorsal pointed tip: Porzana parva, P. porzana;

- obliquely cut, with a blunt dorsal tip: Anthropoides spp.;

- slightly obliquely cut, with a slight bulge, with a pointed dorsal tip: Grus spp.;

- small, pointed tip in the middle: Fulica spp., Gallinula spp., Rallus spp.;

- large, pointed tip in the middle: Crex spp.;

b). The arc of the margo dorsalis:

- the strong bulge is cut: Crex spp.;

- the slight bulge is cut: Fulica spp., Gallinula spp.;

- wide, regular bulge: Porzana parva, P. porzana, Rallus aquaticus;

- moderate, regular bulge: Anthropoides spp., Grus, Otis tarda, O. tetrax;

c). The shape of the facies articularis phalangealis:

- slightly wavy and oblique, with a protruding dorsal projection: Anthropoides spp., Grus spp., Otis tarda, O. tetrax;

- straight and wavy: Crex spp., Gallinula spp., Porzana porzana, Rallus spp.;

- slightly protuberant, with a small pointed ventral tip: Fulica spp.;

- strongly protuberant, with an unrounded protruding ventral end: Porzana parva;

In the case of plowers, shanks, sandpipers, terns, marsh terns, and auks (Figure 7/11, Figure 8/1-12, Figure 9/1-6):

a). Shape of facies articularis metacarpalis:

- strongly protuberant, with a large and pointed dorsal projection: Calidris spp., Charadrius spp.;

- strongly protuberant, with a small and pointed dorsal projection: Lymnocryptes spp.;

- slightly protuberant, with a small and pointed dorsal projection: Arenaria spp., Gallinago spp., Himantopus spp.;

- slightly protuberant: Tringa erythropus, T. totanus;

- strongly oblique, with a well-developed and pointed dorsal projection: Glareola spp., Philomachu spp.s, Pluvialis spp., Recurvirostra spp.;

- oblique and slightly protuberant, with a protruding dorsal projection: Tringa hypoleucos; 


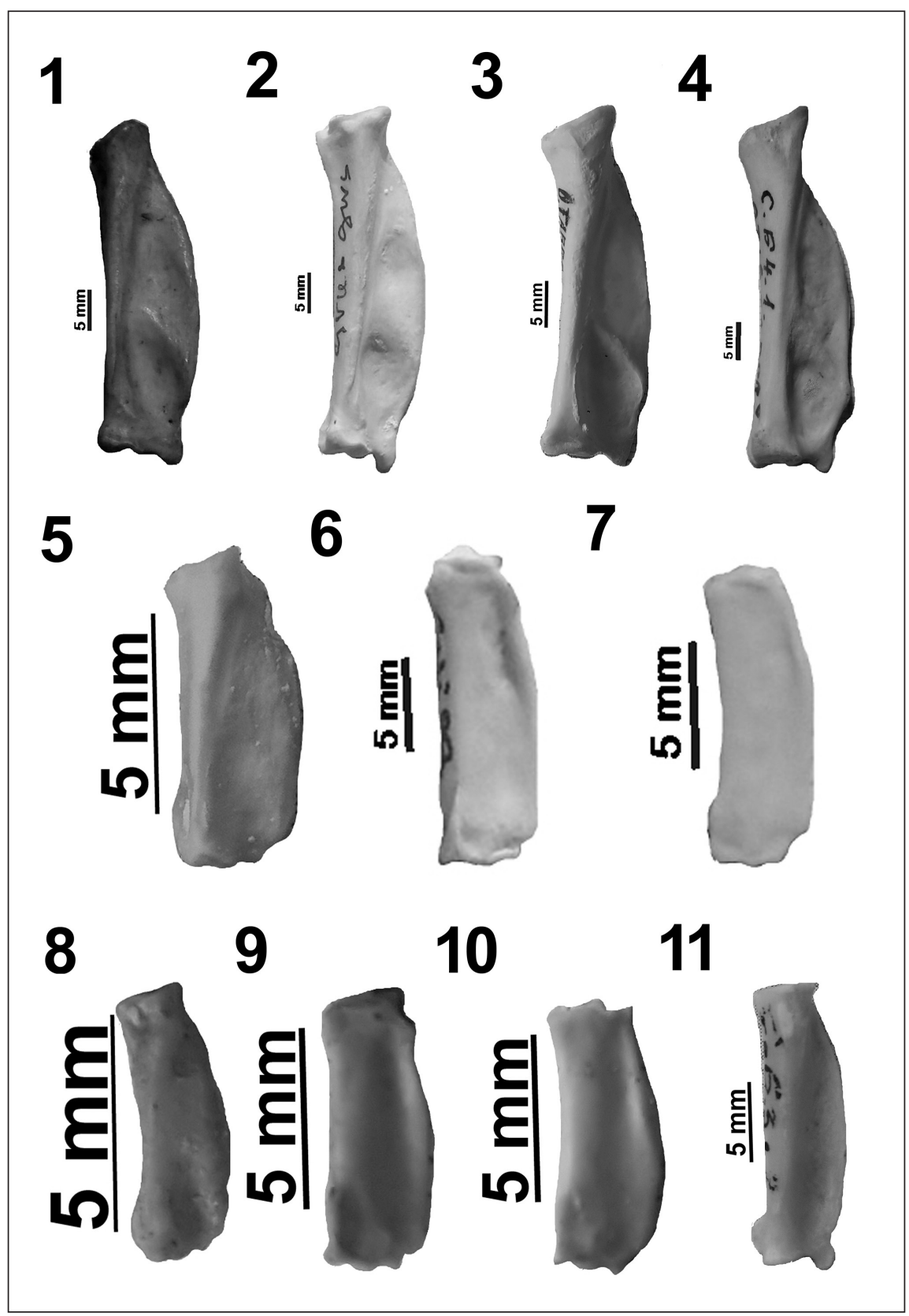

Figure 7. Left phalanx proximalis digiti majoris (ventral aspect)

7. ábra Bal oldali kézujjperc (1. ujjperc, Il. ujj, hasi nézet)

1. Anthropoides virgo (Linnaeus, 1758); 2. Grus grus (Linnaeus, 1758); 3. Otis tarda (Linnaeus, 1758); 4. Otis tetrax (Linnaeus, 1758); 5. Crex crex (Linnaeus, 1758); 6. Fulica atra (Linnaeus, 1758); 7. Gallinula chloropus (Linnaeus, 1758); 8. Porzana parva (Scopoli, 1769); 9. Porzana porzana (Linnaeus, 1758); 10. Rallus aquaticus (Linnaeus, 1758); 11. Uria aalge (Pontoppidan, 1763) 


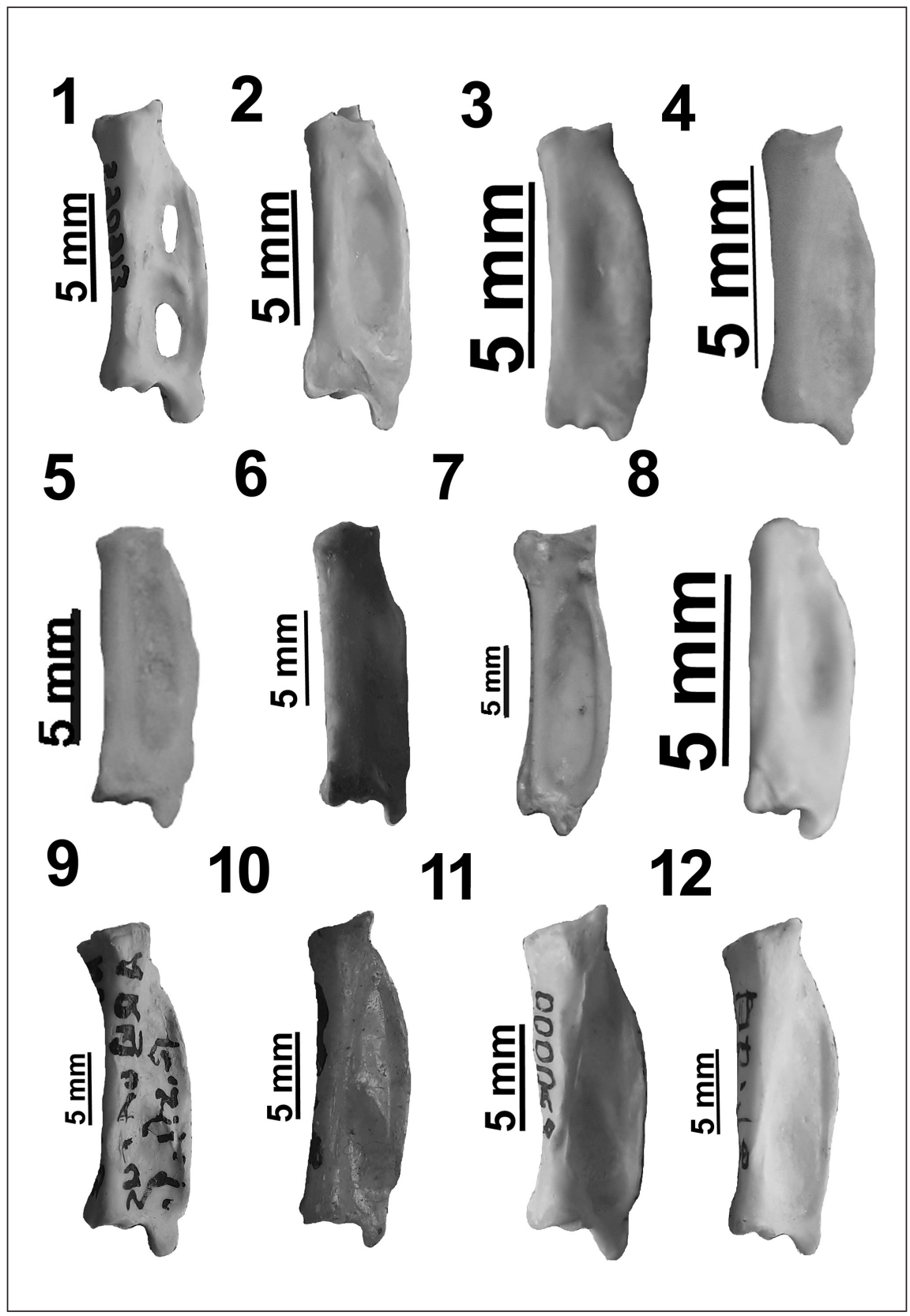

Figure 8. Left phalanx proximalis digiti majoris (ventral aspect)

8. ábra Bal oldali kézujjperc (1. ujjperc, Il. ujj, hasi nézet)

1. Glareola pratincola (Linnaeus, 1766); 2. Arenaria intrepres (Linnaeus, 1758); 3. Calidris alpina (Brehm, 1822); 4. Charadrius alexandrinus (Linnaeus, 1758); 5. Gallinago gallinago (Linnaeus, 1758); 6. Himantopus himantopus (Linnaeus, 1758); 7. Limosa limosa (Linnaeus, 1758); 8. Lymnocryptes minimus (Brünnich, 1764); 9. Numenius arquatus (Linnaeus, 1758); 10. Phylomachus pugnax (Linnaeus, 1758); 11. Pluvialis squatarola (Linnaeus, 1758); 12. Recurvirostra avosetta (Linnaeus, 1758) 
- oblique, with a well-developed and blunt dorsal projection: Scolopax spp.;

- slightly obliquely cut, with a straight ventral end and a small dorsal tip: Numenius spp.;

- concave: Limosa spp., Tringa nebularis;

- with a strongly protruding pointed conelike tip on the ventral side: Vanellus spp.;

- straight, with a dorsally protruding small pointed projection: Uria spp.;

b). The arc of the margo dorsalis:

- the bulge is cut: Glareola spp., Arenaria spp., Himantopus spp., Vanellus spp.;

- the arc of the bulge is symmetrical: Calidris spp., Charadrius spp., Gallinago spp., Lymnocryptes spp., Limosa spp., Numenius spp., Philomachus spp., Pluvialis spp., Recurvirostra spp., Scolopax spp., Tringa erythropus, T. hypoleucos, T. nebularia, T. totanus, Uria spp.;

c). The shape of the facies articularis phalangealis:

- wavy, with a slightly protruding dorsal projection: Calidris spp.;

- wavy, with a strongly protruding, blunt dorsal projection: Glareola spp., Arenaria spp., Charadrius spp., Gallinago spp., Himmantopus spp., Lymnocryptes spp., Limosa spp., Numenius spp., Phylomachus spp., Pluvialis spp., Recurvirostra spp., Scolopax spp., Vanellus spp., Tringa erythropus, T. hypoleucos, T. nebularia, T. totanus;

- convex, with a protuberant ventral and bluntly protruding dorsal projection: Uria spp.;

In the case of seagulls and skuas (Figure 9/7-12):

a). Shape of facies articularis metacarpalis:

- oblique and slightly protuberant, with a protruding dorsal projection: Larus minutus, L. ridibundus, Stercorarius spp.;

- oblique, with a well-developed and pointed dorsal projection: Chlidonias spp., Larus canus;

- asymmetrically protruding in the middle: Sterna spp.;

b). The arc of the margo dorsalis:

- the bulge is cut: Larus minutus, Sterna spp.;

- the bulge has a symmetrical arc: Chlidonias spp., Larus canus, L. ridibundus, Stercorarius spp;

c). The shape of the facies articularis phalangealis:

- slightly obliquely convex, with a well-developed and blunt ventral and dorsal projection: Chlidonias spp., Larus canus, L. minutus, L. ridibundus, Stercorarius spp., Sterna spp.;

In the case of partridges, quails and junglefowls (Figure 10/1-4):

a). Shape of facies articularis metacarpalis:

- concave: Gallus spp.;

- straight line: Alectoris spp.;

- obliquely wavy, lifting from the ventral end towards the dorsal: Coturnix spp.;

- straight wavy: Perdix spp.;

b). The arc of the margo dorsalis:

- slightly protuberant and forms a regular arc: Alectoris spp.;

- the arc is regularly and strongly protuberant: Gallus spp.; 


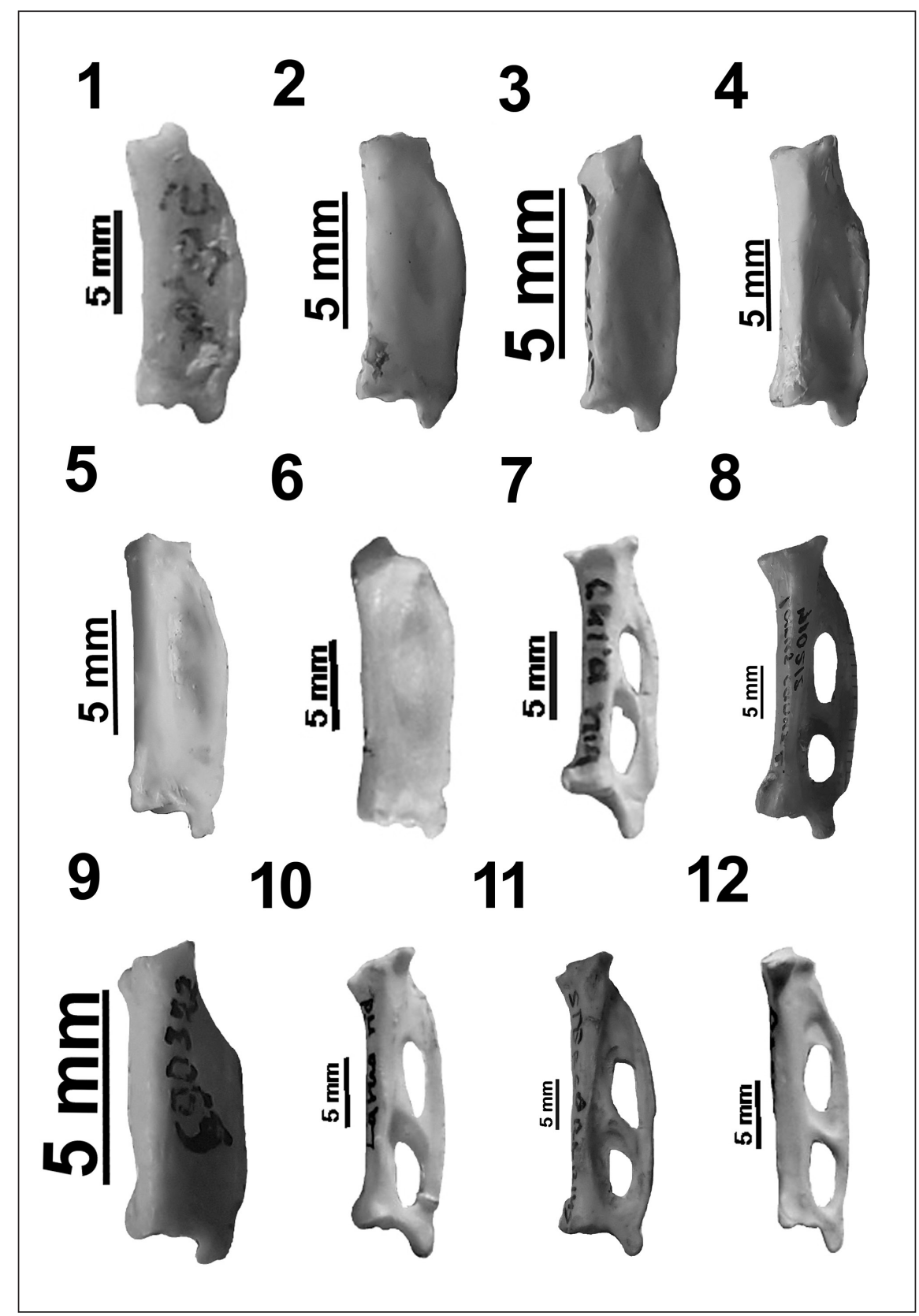

Figure 9. Left phalanx proximalis digiti majoris (ventral aspect)

9. ábra Bal oldali kézujjperc (1. ujjperc, II. ujj, hasi nézet)

1. Scolopax rusticola (Linnaeus, 1758); 2. Tringa erythropus (Pallas, 1764); 3. Tringa hypoleucos (Linnaeus, 1758); 4. Tringa nebularia (Gunnerus, 1767); 5. Tringa totanus (Linnaeus, 1758); 6. Vanellus vanellus (Linnaeus, 1758); 7. Chlidonias niger (Linnaeus, 1758); 8. Larus canus (Linnaeus, 1758); 9. Larus minutus (Pallas, 1766); 10. Larus ridibundus (Linnaeus, 1758); 11. Stercorarius pomarinus (Temminck, 1815); 12. Sterna hirundo (Linnaeus, 1758) 


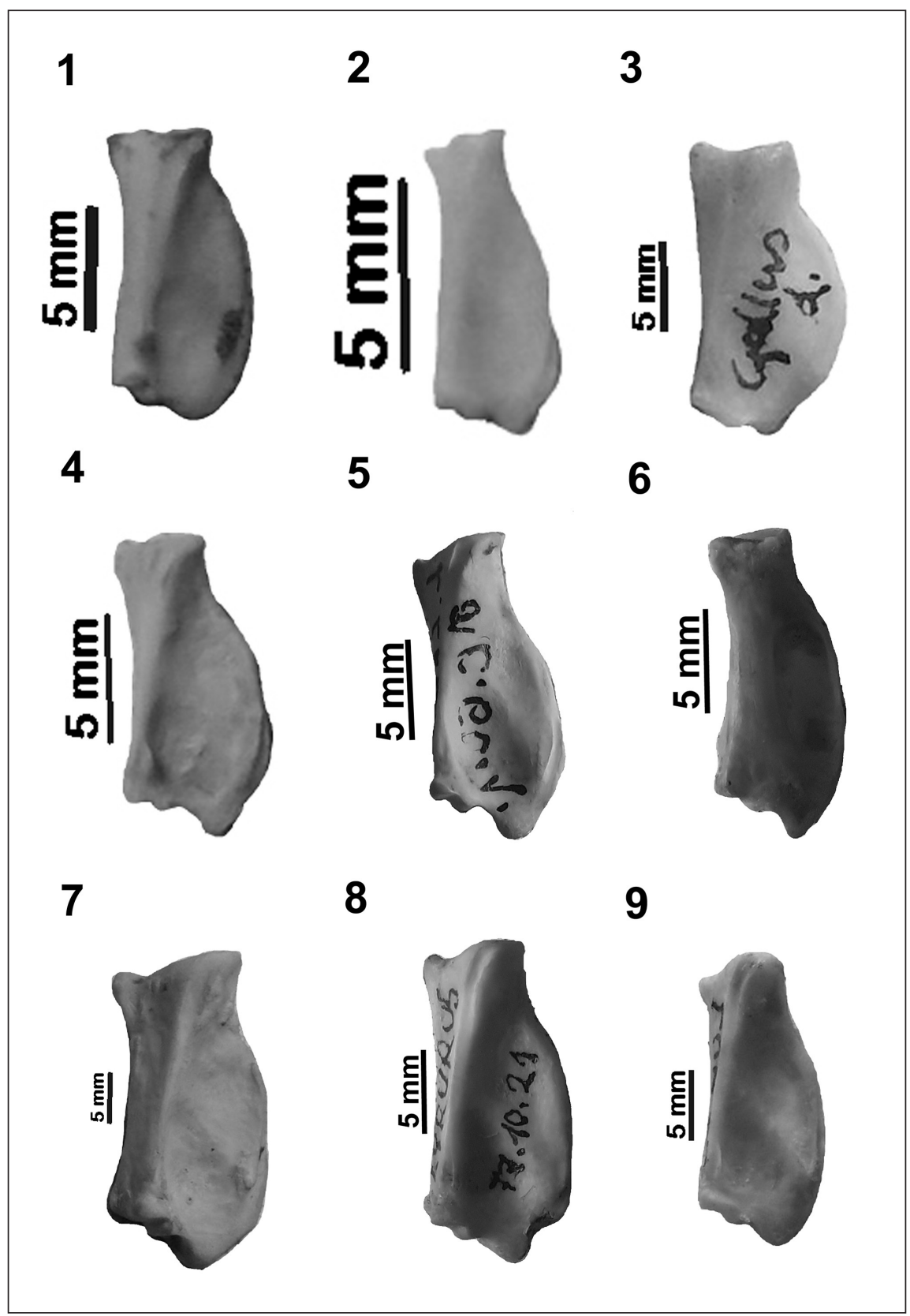

Figure 10. Left phalanx proximalis digit majoris (ventral aspect)

10. ábra Bal oldali kézujjperc (1. ujjperc, II. ujj, hasi nézet)

1. Alectoris graeca (Meisner, 1804); 2. Coturnix coturnix (Linnaeus, 1758); 3. Gallus gallus domesticus (Linnaeus, 1758); 4. Perdix perdix (Linnaeus, 1758); 5. Lagopus lagopus (Linnaeus, 1758); 6. Lagopus mutus (Montin, 1776); 7. Tetrao urogallus (Linnaeus, 1758); 8. Tetrao tetrix (Linnaeus, 1758); 9. Tetrastes bonasia (Linnaeus, 1758) 
- the slightly and irregularly protuberant arc is wavy: Coturnix spp.;

- the strongly and irregularly protuberant arc is wavy: Perdix spp.;

c). The shape of the facies articularis phalangealis:

- obliquely wavy, with a strongly protruding dorsal projection: Perdix spp.;

- obliquely wavy, with a slightly protruding dorsal projection: Alectoris spp., Gallus spp.;

- obliquely straight, with a slightly protruding dorsal projection: Coturnix spp.;

In the case of grouse (Figure 10/5-9):

a). Shape of facies articularis metacarpalis:

- obliquely and slightly protuberant, with a strongly protruding ventral tip: Tetrao spp.;

- strongly protuberant, with an slightly protruding ventral projection: Tetrastes spp.;

- obliquely cut straight, with a slightly protruding ventral projection: Lagopus spp.;

b). The arc of the margo dorsalis:

- forms a strongly protuberant and regular arc: Tetrastes spp.;

- strongly protuberant, with an obliquely cut edge: Lagopus spp.;

- strongly protuberant with a slightly oblique and flattened edge: Tetrao spp.;

c). Shape of facies articularis phalangealis:

- obliquely wavy, with a strongly protruding conelike dorsal projection: Lagopus spp.;

- obliquely wavy, with a strongly protruding blunt conelike dorsal projection: Tetrao spp.;

- obliquely wavy, with a rounded protruding dorsal projection: Tetrastes spp.;

\section{Conclusions}

In the case of examined waterbird species, the shape and size of the phalanx is quite diverse. We can examine significant cases of sexual dimorphism (Otis) in certain species. This greatly favors male specimen. It may be expedient to compare the changes in form of the examined characteristics with the differences in size, since there can be significant differences within families or even genera. Similarities in form can occur in species of different families or genera.

The first phalanx of the second wing-finger of Galliformes is typically short and wide, with the exception of the Coturnix wing phalanx, which is longer and slimmer. In the case of Phasianidae, the shape proximal end is diverse, while the dorsal edge forms a strongly protuberant arc. The distal end obliquely descends to the dorsal projection, which is more or less strongly protruding. The proximal end in the case of Tetraonidae has a diverse form. The dorsal edge is strongly protuberant but different, while the distal end is descending in an oblique and wavy fashion to the dorsal projection, which is quite strongly protuberant but differs in shape.

\section{Acknowledgements}

The author wishes to express his gratitude to Mihály Gasparik for access to recent bird bone collection in the Natural History Museum of Hungary Budapest, to József Vuts and Lóránd Abos for the language revision. 
Table 1. Size table of phalanx proximalis digiti majoris

A - total length of bone $(\mathrm{mm}) ; \mathrm{C}$ - breadth of proximal end; $\mathrm{E}$ - breadth of corpus; F breadth of distal end. New name (Gill et al. 2020)

1. táblázat A phalanx proximalis digiti majoris mérettáblázata

$A$ - teljes hossz $(\mathrm{mm}) ; C$ - proximális vég szélessége; $E$ - a test szélessége; $F$ - disztális vég szélessége. Új név - New name (Gill et al. 2020)

\begin{tabular}{|c|c|c|c|c|c|}
\hline Species & New genus name & A & C & $\mathbf{E}$ & $\mathbf{F}$ \\
\hline & Gill et al. 2019 & & & & \\
\hline \multicolumn{6}{|l|}{ Gaviiformes } \\
\hline Gavia arctica & & 26.50 & 5.50 & 8.00 & 7.00 \\
\hline Gavia stellata & & 22.50 & 6.00 & 7.00 & 5.50 \\
\hline \multicolumn{6}{|l|}{ Podicipediformes } \\
\hline Podiceps auritus & & 14.20 & 2.50 & 3.00 & 2.50 \\
\hline Podiceps cristatus & & 20.00 & 3.50 & 4.50 & 3.70 \\
\hline Podiceps grisegena & & 19.00 & 3.00 & 4.00 & 3.00 \\
\hline Podiceps nigricollis & & 15.00 & 2.50 & 3.00 & 2.50 \\
\hline \multicolumn{6}{|l|}{ Pelecaniformes } \\
\hline Pelecanus crispus & & 68.00 & 17.00 & 26.00 & 16.00 \\
\hline Pelecanus onocrotalus & & 71.00 & 18.00 & 26.00 & 18.00 \\
\hline Phalacrocorax carbo & & 33.00 & 6.00 & 9.00 & 6.50 \\
\hline Phalacrocorax pygmaeus & Microcarbo & 19.50 & 3.50 & 6.00 & 4.00 \\
\hline \multicolumn{6}{|l|}{ Ardeiformes } \\
\hline Ardea cinerea & & 35.00 & 6.50 & 11.00 & 8.00 \\
\hline Ardea purpurea & & 28.00 & 4.50 & 9.00 & 7.00 \\
\hline Ardeola ralloides & & 16.00 & 3.00 & 5.00 & 3.50 \\
\hline Bubulcus ibis & & 31.00 & 6.00 & 10.00 & 8.00 \\
\hline Botaurus stellaris & & 27.00 & 4.50 & 7.50 & 6.00 \\
\hline Egretta garzetta & & 20.50 & 5.00 & 6.00 & 5.00 \\
\hline Nycticorax nycticorax & & 20.00 & 3.00 & 10.50 & 5.00 \\
\hline Ciconia ciconia & & 46.00 & 11.00 & 11.50 & 11.00 \\
\hline Ciconia nigra & & 50.00 & 8.00 & 13.00 & 12.00 \\
\hline Platalea leucorodia & & 39.00 & 8.00 & 10.50 & 8.00 \\
\hline Plegadis falcinellus & & 22.00 & 3.50 & 7.50 & 5.00 \\
\hline Phoenicopterus ruber & & 36.00 & 5.00 & 8.00 & 6.00 \\
\hline \multicolumn{6}{|l|}{ Anseriformes } \\
\hline Anser albifrons & & 40.00 & 7.00 & 11.50 & 11.00 \\
\hline Anser anser & & 46.00 & 9.50 & 10.50 & 10.00 \\
\hline
\end{tabular}




\begin{tabular}{|c|c|c|c|c|c|}
\hline Species & New genus name & A & C & $\mathbf{E}$ & $\mathbf{F}$ \\
\hline Anser erythropus & & 33.00 & 6.00 & 10.00 & 7.00 \\
\hline Anser fabalis & & 41.00 & 7.50 & 11.50 & 10.00 \\
\hline Branta bernicla & & 29.00 & 5.00 & 9.00 & 7.00 \\
\hline Branta ruficollis & & 25.00 & 6.50 & 7.50 & 5.50 \\
\hline Tadorna tadorna & & 34.00 & 6.00 & 10.50 & 8.00 \\
\hline Cygnus cygnus & & 61.00 & 10.50 & 15.00 & 11.00 \\
\hline Cygnus olor & & 59.00 & 11.00 & 12.00 & 11.00 \\
\hline Anas acuta & & 22.00 & 3.50 & 6.50 & 6.00 \\
\hline Anas clypeata & Spatula & 20.50 & 5.00 & 5.50 & 5.00 \\
\hline Anas crecca & & 15.00 & 3.00 & 5.00 & 4.00 \\
\hline Anas penelope & Mareca & 20.00 & 4.00 & 6.50 & 4.00 \\
\hline Anas platyrhynchos & & 23.00 & 4.50 & 7.00 & 5.00 \\
\hline Anas querquedula & Spatula & 15.00 & 4.00 & 6.00 & 4.50 \\
\hline Anas strepera & Mareca & 21.00 & 4.50 & 6.50 & 5.00 \\
\hline Aythya ferina & & 19.50 & 4.00 & 5.50 & 4.50 \\
\hline Aythya fuligula & & 18.00 & 3.50 & 5.00 & 4.50 \\
\hline Aythya marila & & 20.00 & 3.50 & 6.00 & 5.00 \\
\hline Aythya nyroca & & 15.50 & 3.50 & 4.50 & 3.50 \\
\hline Bucephala clangula & & 21.00 & 4.50 & 5.50 & 4.00 \\
\hline Clangula hyemalis & & 19.50 & 4.50 & 7.00 & 4.50 \\
\hline Melanitta nigra & & 24.00 & 4.00 & 6.00 & 5.00 \\
\hline Mergus albellus & Mergellus & 18.00 & 3.50 & 5.00 & 5.00 \\
\hline Mergus merganser & & 25.00 & 4.00 & 7.00 & 6.50 \\
\hline Mergus serrator & & 20.50 & 4.00 & 5.50 & 5.00 \\
\hline Somateria mollissima & & 29.00 & 6.50 & 10.00 & 7.00 \\
\hline \multicolumn{6}{|l|}{ Gruiformes } \\
\hline Anthropoides virgo & Grus & 42.50 & 7.50 & 17.00 & 11.00 \\
\hline Grus grus & & 51.00 & 11.00 & 13.00 & 10.00 \\
\hline Otis tarda & & 56.00 & 10.00 & 15.00 & 13.00 \\
\hline Otis tetrax & Tetrax & 20.00 & 4.20 & 6.00 & 6.00 \\
\hline \multicolumn{6}{|l|}{ Ralliformes } \\
\hline Crex crex & & 9.50 & 2.50 & 3.50 & 3.00 \\
\hline Fulica atra & & 18.00 & 4.00 & 5.50 & 5.00 \\
\hline Gallinula chloropus & & 12.50 & 3.20 & 4.00 & 3.00 \\
\hline Porzana parva & Zapornia & 6.00 & 1.50 & 2.00 & 2.50 \\
\hline Porzana porzana & & 8.00 & 2.50 & 3.00 & 2.50 \\
\hline Rallus aquaticus & & 8.50 & 2.50 & 3.50 & 2.50 \\
\hline
\end{tabular}




\begin{tabular}{|c|c|c|c|c|c|}
\hline Species & New genus name & A & C & $\mathbf{E}$ & $\mathbf{F}$ \\
\hline \multicolumn{6}{|l|}{ Charadriiformes } \\
\hline Uria aalge & & 20.00 & 4.00 & 6.00 & 6.50 \\
\hline Glareola pratincola & & 15.20 & 3.00 & 4.50 & 5.00 \\
\hline Arenaria interpres & & 12.20 & 2.00 & 4.00 & 3.50 \\
\hline Calidris alpina & & 9.00 & 2.20 & 2.70 & 2.30 \\
\hline Charadrius alexandrinus & & 8.00 & 3.00 & 3.50 & 3.50 \\
\hline Gallinago gallinago & & 13.50 & 2.30 & 3.80 & 3.00 \\
\hline Himantopus himantopus & & 17.00 & 3.00 & 5.00 & 4.80 \\
\hline Limosa limosa & & 15.50 & 3.80 & 5.00 & 3.50 \\
\hline Lymnocryptes minimus & & 8.00 & 2.00 & 2.70 & 2.00 \\
\hline Numenius arquata & & 26.50 & 5.00 & 8.00 & 5.00 \\
\hline Philomachus pugnax & & 15.00 & 3.00 & 5.00 & 4.50 \\
\hline Pluvialis squatarola & & 17.00 & 4.00 & 5.20 & 5.00 \\
\hline Recurvirostra avosetta & & 20.00 & 4.00 & 6.20 & 5.00 \\
\hline Scolopax rusticola & & 19.50 & 3.00 & 6.00 & 4.50 \\
\hline Tringa erythropus & & 21.20 & 2.50 & 3.60 & 3.00 \\
\hline Tringa hypoleucos & & 8.80 & 1.70 & 2.50 & 2.00 \\
\hline Tringa nebularia & & 26.50 & 4.00 & 5.30 & 5.00 \\
\hline Tringa totanus & & 13.00 & 2.80 & 4.50 & 3.00 \\
\hline Vanellus vanellus & & 16.00 & 3.50 & 5.20 & 4.00 \\
\hline Chlidonias niger & & 17.50 & 3.50 & 5.50 & 3.00 \\
\hline Larus canus & & 28.00 & 6.50 & 7.50 & 7.50 \\
\hline Larus minutus & Hidrocoloeus & 8.30 & 2.00 & 3.00 & 3.00 \\
\hline Larus ridibundus & Chroicocephalus & 24.00 & 5.00 & 8.50 & 5.50 \\
\hline Stercorarius pomarinus & & 32.00 & 6.00 & 8.00 & 5.00 \\
\hline Sterna hirundo & & 22.00 & 4.00 & 6.50 & 5.50 \\
\hline \multicolumn{6}{|l|}{ Galliformes } \\
\hline Alectoris graeca & & 12.50 & 4.00 & 5.20 & 3.50 \\
\hline Coturnis coturnix & & 7.50 & 2.00 & 3.20 & 2.80 \\
\hline Gallus domesticus & & 15.00 & 5.00 & 7.50 & 5.50 \\
\hline Perdix perdix & & 11.50 & 3.50 & 5.50 & 4.50 \\
\hline Lagopus lagopus & & 15.50 & 4.50 & 7.50 & 5.50 \\
\hline Lagopus mutus & L. mute & 15.50 & 4.50 & 6.00 & 4.50 \\
\hline Tetrao tetrix & & $20-00$ & 6.00 & 11.00 & 6.00 \\
\hline Tetrao urogallus & & 32.00 & 12.50 & 14.00 & 10.50 \\
\hline Tetrastes bonasia & & 21.00 & 6.00 & 8.50 & 6.20 \\
\hline
\end{tabular}




\section{References}

Baumel, J. J., King, A. S., Lucas, A. M., Breazile, J. E. \& Evans, H. E. 1979. Nomina anatomica avium. Academical Press, London

Brodkorb, P. 1963. Catalogue of fossil birds. Part 1. (Archaeopterygiformes through Ardeiformes). - Bulletin of the Florida State Museum, Biological Sciences 7: 179-293.

Cohen, A. \& Serjeantson, D. 1996. A manual for the identification of bird bones from archaeological sites (revised ed.). - Archetype Publications, London

Feduccia, J. A. 1967. Ciconia maltha and Grus americana from the Upper Pliocene of Idaho. - The Wilson Bulletin 79(3): 316-318.

Gilbert, B. M., Martin, L. D. \& Savage, H. G. 1981. Avian Osteology. - Library of Congress, Wyoming

Gill, F., Donsker, D. \& Rasmussen, P. (eds.) 2020. IOC World Bird List. - DOI: 10.14344/IOC.ML.10.2.

Hackett, S. J., Kimball, R. T., Reddy, S., Bowie, R. C., Braun, E. L., Braun, M. J., Chojnowski, J. L., Cox, W. A., Han, K. L., Harshman, J., Huddleston, C. J., Marks, B. D., Miglia, K. J., Moore, W. S., Sheldon, F. H., Steadman, D. W., Witt, C. C. \& Yuri, T. 2008. A Phylogenomic study of birds reveals their evolutionary history. - Science 320(5884): 1763-1768. DOI: 10.1126/science.1157704

Kessler, E. 2013. A Kárpát-medence madárvilágának őslénytani kézikönyve [Paleontological Handbook of Birdlife in Carpathian Basin]. - Könyvmühely, Miskolc (in Hungarian)

Kessler, J. (E.) 2015. Osteological guide of songbirds from Central Europe. - Ornis Hungarica 23(2): $62-156$. DOI: 10.1515/orhu-2015-0009

Kessler, J. (E.) 2016a Picidae in the European fossil, subfossil and recent bird faunas and their osteological characteristics. - Ornis Hungarica 24(1): 96-114. DOI: 10.1515/orhu-2016-0009

Kessler, J. (E.) 2016b Evolution and skeletal characteristics of European owls. - Ornis Hungarica 24(2): 65-103. DOI: 10.1515/orhu-2016-0009

Kessler, J. (E.) 2019. Pigeons, sandgrouse, cuckoos, nightjars, rollers, bee-eaters, kingfishers and swifts in the European fossil avifauna and their osteological characteristics. - Ornis Hungarica 27(1): 132-165. DOI: 10.2478/orhu-2019-0009

Kessler, J. (E.) 2020. Evolution of Corvids and their presence in the Neogene and the Quaternary in the Carpathian Basin. - Ornis Hungarica 28(1): 121-168. DOI: 10.2478/orhu-2020-0009

Milne-Edwards, A. 1867-1868. Recherches anatomiques et paléontologiques pour servir àl'histoire des oiseaux fossiles de la France,Vol. 1. [Anatomical and paleontological research to be used in the history of the fossil birds of France, Vol. 1.]. - Paris: Victor Masson et Fils (in French)

Smith, N. D. 2010. Phylogenetic analysis of Pelecaniformes (Aves) based on osteological data: implications for waterbird phylogeny and fossil calibration studies. - Plos One 5(10): e13354. DOI: 10.1371/journal. pone.0013354

Solti, B. 1980. Beiträge zur Kenntnis der Osteologie des Gerfalken (Falco rusticolus L., 1758) [Contributions to the knowledge of the osteology of the Gyrfalcon (Falco rusticolus L., 1758)]. - Folia Historico-Naturalia Musei Matraensis 6: 189-204. (in German)

Solti, B. 1981a Vergleichend-osteologische Untersuchungen am Skelettsystem der Falkenarten Falco cherrug Gary und Falco peregrinus Tunstall [Comparative osteological studies on the skeletal system of the falcon species Falco cherrug Gary and Falco peregrinus Tunstall]. - Vertebrata Hungarica 20: 75-125. (in German)

Solti, B. 1981b Osteologische Untersuchungen an Falco biarmicus Temminck, 1825 [Osteological investigations on Falco biarmicus Temminck, 1825]. - Folia Historico-Naturalia Musei Matraensis 7: 135-151. (in German)

Solti, B. 1996. The comparative osteomorphological study of the European small-statured falcons (Aves: Falconidae). - Folia Historico-Naturalia Musei Matraensis 21: 5-282.

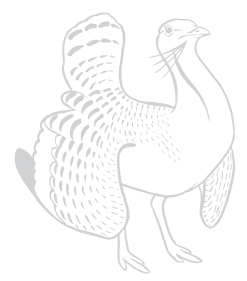

